\title{
Urban Land-Cover Dynamics in Arid China Based on High-Resolution Urban Land Mapping Products
}

\author{
Tao Pan ${ }^{1,2}$, Dengsheng Lu ${ }^{3}$, Chi Zhang ${ }^{1, *}$, Xi Chen ${ }^{1}$, Hua Shao ${ }^{1}$, Wenhui Kuang ${ }^{4}$, \\ Wenfeng Chi ${ }^{4,5}$, Zhengjia Liu ${ }^{4,6}$, Guoming $\mathrm{Du}^{7}$ and Liangzhong Cao ${ }^{1,2}$ \\ 1 State Key Laboratory of Desert and Oasis Ecology, Xinjiang Institute of Ecology and Geography, \\ Chinese Academy of Sciences, Urumqi 830011, China; pantaohlj@163.com (T.P.); chenxi@ms.xjb.ac.cn (X.C.); \\ shaohua@ms.xjb.ac.cn (H.S.); liangzhong.cao@outlook.com (L.C.) \\ 2 University of Chinese Academy of Sciences, Beijing 100049, China \\ 3 Key Laboratory of Carbon Cycling in Forest Ecosystems and Carbon Sequestration of Zhejiang Province, \\ School of Environmental \& Resource Sciences, Zhejiang Agriculture and Forestry University, \\ Lin An 311300, China; luds@zafu.edu.cn \\ 4 Institute of Geographic Sciences and Natural Resources Research, Chinese Academy of Sciences, \\ Beijing 100101, China; kuangwh@1reis.ac.cn (W.K.); chiwenfeng2005@126.com (W.C.); \\ Liuzj@1reis.ac.cn (Z.L.) \\ 5 Inner Mongolia University of Finance and Economics, Inner Mongolia, Hohhot 010018, China \\ 6 Institute of Remote Sensing and Digital Earth, Chinese Academy of Sciences, Beijing 100094, China \\ 7 College of Resources and Environmental Sciences, Northeast Agricultural University, Harbin 150030, China; \\ nmgdgm@163.com \\ * Correspondence: zc@ms.xjb.ac.cn; Tel.: +86-186-9032-1105
}

Academic Editors: Conghe Song, Junxiang Li, Weiqi Zhou, Soe Myint and Prasad S. Thenkabail Received: 24 May 2017; Accepted: 12 July 2017; Published: 14 July 2017

\begin{abstract}
Rapid urbanization has occurred in northwestern China, threatening the sustainability of its fragile dryland ecosystems. A lack of precise urban land-cover information has limited our understanding on the urbanization in the dryland. Here, we examined urban land-cover changes from 2000 to 2014 in 21 major cities that comprise over 50\% of the developed land in arid China, using Landsat Enhanced Thematic Mapper Plus and Operational Land Imager data, and a hybrid classification method. The 15-m resolution urban land-cover products (including impervious surfaces, vegetation, bare soil, and water bodies) had an overall accuracy of $90.37 \%$. Based on these new land use products, we found the urbanization in arid China was characterized by the dramatic expansion of impervious surface $(+13.23 \%)$ and reduction of bare soil $(-13.41 \%)$, while the proportions of vegetation $(+0.27 \%)$ and water $(-0.10 \%)$ remained stable. The observed dynamic equilibrium of vegetated ratio implies an increasing harmonization of urbanization and greening, which was particularly important for the sustainability of fragile urban ecosystems in arid regions. From an economic perspective, gross domestic product and population were significantly correlated with impervious surfaces, and oasis cities displayed a stronger ability to attract new residents than desert cities.
\end{abstract}

Keywords: urban expansion; land-cover change; greening; precise mapping products; arid China

\section{Introduction}

Humans have experienced rapid urban expansion. As of 2008, more than half of the world's population lived in urban areas [1]. This number is expected to reach 66 percent by 2050, and this ongoing increase is driving the rapid expansion of urban areas [2]. At present, approximately $5 \%$ of global land has been converted to urban areas; and urbanization has become an important factor in land use/cover changes on a global scale [3,4]. By 2030, the area of the world covered by urban land 
uses will triple compared to 2000 values [5], which will impact global biodiversity [6], climate [7], and hydrology [8]. The sustainability of an increasingly urbanized world is closely related to the structure of urban landscapes characterized by combinations of different land-cover types. Urban land-cover information has become an indicator of the ecological environment and climatic effects over different spatial and temporal scales [9-12]. Analysing the land-cover dynamics associated with urbanization in arid China also represents a potential avenue for research regarding the impact of urbanization on the global environment [12-14].

Arid regions are characterized by dry climates, sparse vegetation, water shortages, limited precipitation, and extremely fragile ecological environments; these characteristics lead to fragile urban ecosystems [15]. These systems are so overwhelmingly dependent on the external environment and socio-economic conditions that urban land-cover in arid regions is characterized by rapid succession and instability [16]. Background surface substrates show strong spatial heterogeneity and low resistance to landscape evolution [17]. A high proportion of the urban population is generally concentrated in a few large cities, such as Urumqi; the sustainability of these cities is particularly fragile [18]. Accurate urban land-cover information is needed to understand fragile urban ecosystems. The economic relationships among cities are weak due to the intervening desert, and the urban attraction effects associated with these cities are limited to the local scale. However, these cities still have strong administrative relationships, and they tend to become regional political, economic, cultural, and traffic centers [19]. Quantitative research into land-cover in these administrative centres may support the effective monitoring of dynamic urban change patterns across the entire arid region.

Satellite images with high spatial resolution, such as QuickBird, are widely used to classify urban land-cover. However, it is difficult to achieve highly accurate classification results when applying automatic classification approaches due to the effects of spectral heterogeneity and the shadows casted by buildings and trees within the same surface type [20,21]. Images with moderate spatial resolution (such as Landsat images, which are easily accessed and have an appropriate spectral resolution) remain an important and popular data source [22]. According to the classification method proposed by Ridd, urban land-cover can be classified into three categories (excluding water) using the vegetation-impervious surface-soil (VIS) model [23]. Lu combined a linear spectral mixture analysis (LSMA) model with VIS to perform mixed pixel decomposition of moderate spatial resolution images in urban areas within humid regions [24,25]. However, the considerable areas of bare soil within urban areas in arid regions and the similarity between the spectral signatures of bare soils with impervious surface areas (ISA) made it especially challenging to accurately evaluate the quantity and distribution of information provided by this method. Zhang et al. [18] described a method that combined LSMA and decision tree classification scheme to improve the accuracy of land-cover classifications during a comparative analysis of land-cover in the arid and semi-arid regions surrounding Urumqi and Phoenix. This paper describes a new strategy for change detection analysis based on this method to provide accurate and reliable urban land-cover information in arid China.

With population growth and economic progress, the cities in arid China have experienced rapid urbanization [26-29]. Ensuring the sustainability of these fragile urban ecosystems requires urban land-cover information and change detection technologies that yield high precision results and consider socio-economic factors. Therefore, the objectives of this study were to (1) create a high-resolution (15 $\mathrm{m})$ urban land-cover dataset for the major cities (i.e., the 21 administrative centres) that comprised more than half of the developed land in arid China; (2) use a change detection analysis strategy to provide dynamic information on urban land-cover in arid China between 2000 and 2014, especially changes in urban greening; and (3) explore the influence of socio-economic factors on urban land-cover changes. 


\section{Materials and Methods}

\subsection{Study Area}

The arid region of China includes Xinjiang, the northern parts of Gansu and Ningxia, and the western part of Inner Mongolia (Figure 1) [30]. The total area of this region is $213.80 \times 10^{4} \mathrm{~km}^{2}$. It has a typical continental monsoon climate with short spring and autumn seasons, hot and dry summer, and long and cold winter. Annual precipitation is generally less than $200 \mathrm{~mm}$, and annual mean temperature is approximately $8^{\circ} \mathrm{C}$ [31]. The area is characterized by complex terrain and landforms with elevations ranging from $-191 \mathrm{~m}$ to $8507 \mathrm{~m}$. Gross domestic product (GDP) increased by 1010.95 billion yuan from 2000 to 2014, and urban population increased by 4.46 million people over the same period. In 2014, constructed areas of all the administrative centers (a total of 21) comprised $53.31 \%$ of the total developed land area (including both cities and towns) in arid China. Therefore, our study focused on the 21 major cities.

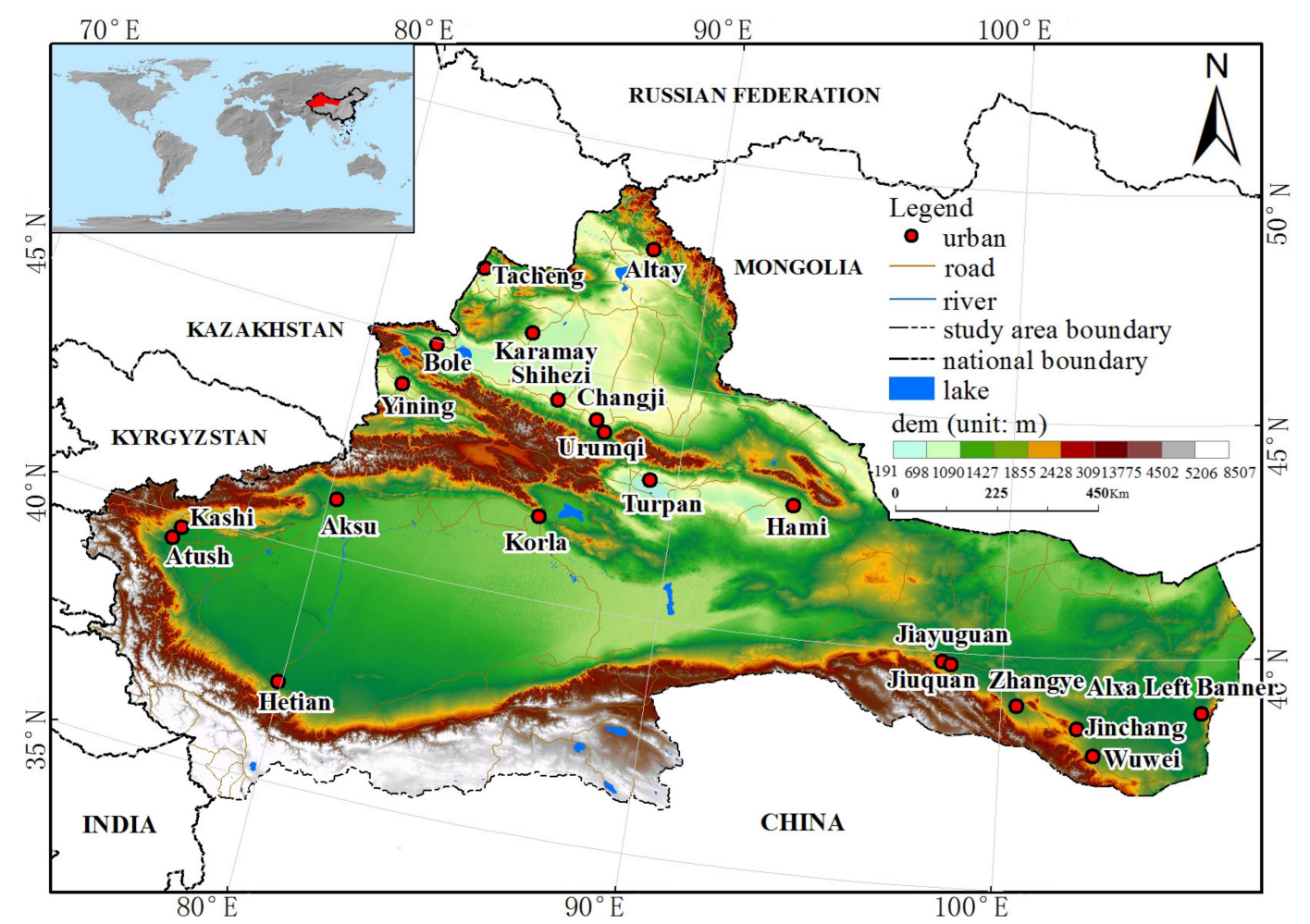

Figure 1. The locations of the arid region in China.

\subsection{Methods}

Figure 2 illustrates how Landsat images were used to classify urban land-cover and the associated change detection analysis strategy. The VIS model and the LSMA were used to generate fraction images of vegetation, soil, low-albedo and high-albedo objects [20]. A decision tree classifier was then applied to produce urban land-cover maps of vegetation, soil, water, and ISA. An overlay analysis was performed using the urban development boundary and the land-cover maps to extract land-cover information within the urban areas. Based on their natural environmental conditions, the cities were classified as desert or oasis cities; the cities in these two categories were further classified as industrial or non-industrial cities based on their social and economic characteristics (Figure 3). Then, the change detection analysis was performed. 


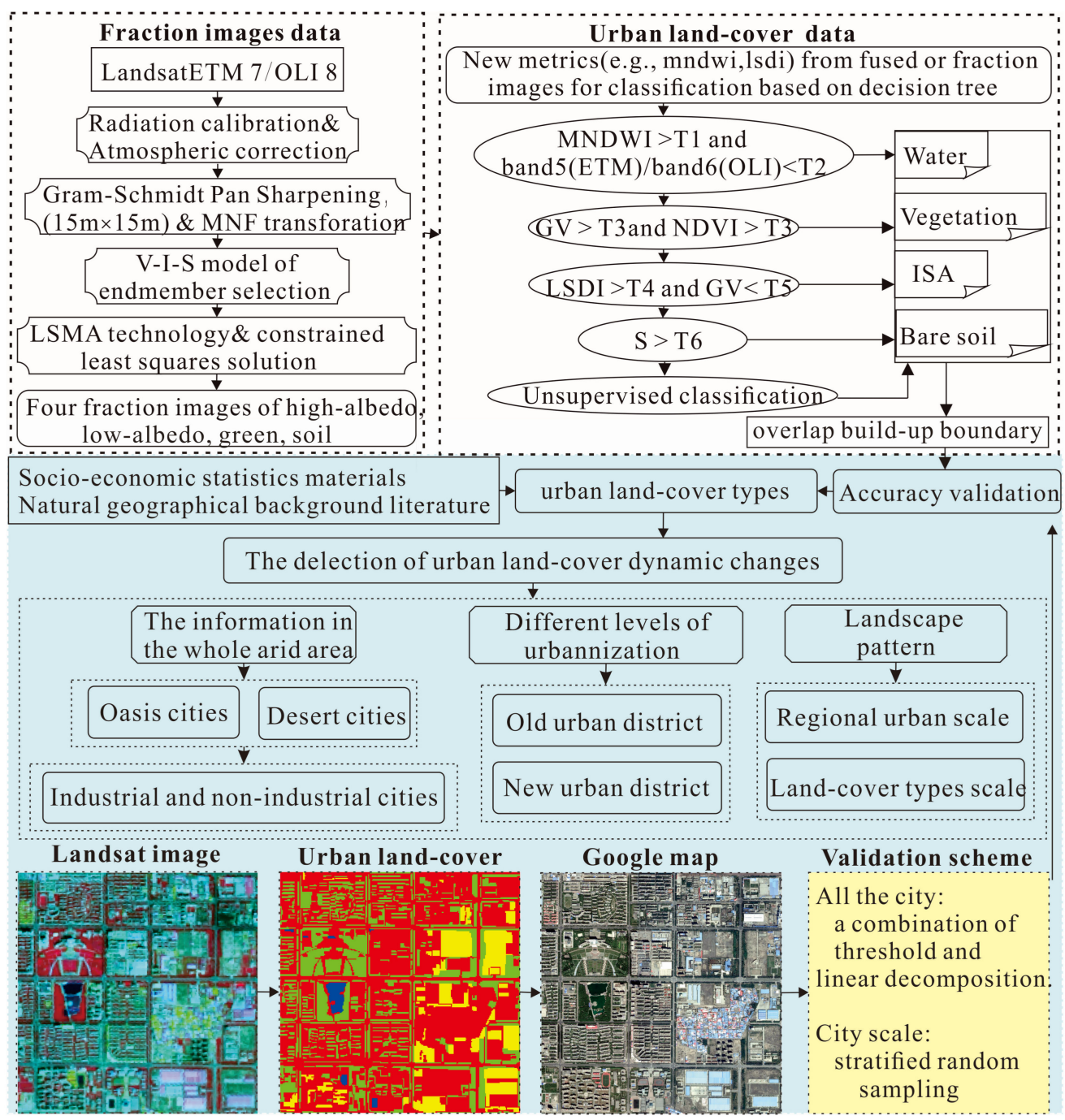

Figure 2. Strategy for change detection analysis using urban Landsat data. Abbreviations: T1, T2, T3, T4, T5, and T6: thresholds (the values of these quantities changed according to the different metrics used in the decision tree classifier); MNF: minimum noise fraction transformation; VIS: vegetation-impervious surfaces-soil model; LSMA: linear spectral mixture analysis; MNDWI: modified normalized difference water index; LSDI: low albedo and soil difference index; NDVI: normalized difference vegetation index; ISA: impervious surface areas; and GV: green vegetation. The urban land-cover map shows part of the city of Shihezi. Colour descriptions: red: ISA; green: GV; yellow: soil; and blue: water body.

\subsubsection{Data Collection and Pre-Processing}

Landsat 7 ETM+ and Landsat 8 OLI (Path: 130-149, Row: 27-34) images from 2000 to 2014 and 1-m resolution Google Earth maps from 2014 were collected in this study. The Landsat images were first examined visually to evaluate image quality [28]. Then, data from July through September were analysed to accurately identify areas and spatial vegetation patterns. The Universal Transverse Mercator (UTM43-48/44-48 for 7 ETM+/8 OLI) coordinate system was re-projected to the Albers Conical Equal Area projection, and the areas and proportions of urban land cover types were calculated using the same coordinate system.

Fast line-of-sight atmospheric analysis spectral hypercubes (FLAASH) was used to conduct the atmospheric calibration. FLAASH is a first-principles atmospheric calibration tool that corrected wavelengths in the visible through near-infrared and shortwave infrared regions. Unlike many other atmospheric correction programs that interpolate radiation transfer properties from a pre-calculated 
database of modelling results, FLAASH incorporated the moderate resolution atmospheric transmission 4 (MODTRAN4) radiation transfer code. The version of MODTRAN4 incorporated into ENVI FLAASH was modified to correct errors in the HITRAN-96 water line parameters [32]. Therefore, ENVI FLAASH is suitable for use with multispectral sensors (such as those onboard the Landsat satellites) and can correct images collected in either vertical (nadir) or slant-viewing geometries [33].

The urban development boundary (build-up boundary in 2000 and 2014, respectively) was determined using the National Land Cover Dataset (NLCD) for China, which was produced by the Chinese Academy of Sciences (http:/ / www.resdc.cn/Datalist1.aspx?FieldTyepID=1,3). The reported average accuracy for this dataset exceeded $90 \%$ [34,35]. Socio-economic data were obtained from the National Bureau of Statistics of China (http:/ /www.stats.gov.cn/tjsj/tjgb/ndtjgb/).

\subsubsection{Data Fusion and Extraction of Fraction Images}

The spatial resolution of remote sensing data is a vital factor for efficiently extracting fraction images, especially for complex arrangements of land-cover types in urban landscapes [36]. Gram-Schmidt spectral sharpening has been shown to be an effective data fusion method for integrating multispectral and panchromatic data to create high-resolution datasets from Landsat images [37]. Thus, this technique was used in this research [38].

Using the VIS model, urban land-cover can be assessed a combination with vegetation, soil, low-albedo, and high-albedo objects [28]. Selecting appropriate endmembers for each component is a key step in this process. A minimum noise fraction transformation was used to transform the multispectral bands into three principal components. Then, four endmembers were identified. A fully constrained least-squares solution was used to decompose the Landsat images into four fraction maps [23].

\subsubsection{Urban Land-Cover Classification and Type Division of Cities}

Spectral bands are commonly used to classify land-cover based on spectral signatures and fraction values. However, the mixed-pixel problem can make it difficult to separate different land use types in arid urban landscapes. For example, the high-albedo fraction image included highly-reflective bare soils and ISA, and the low-albedo fraction image contained shadows, dark ISA and water. Previous research has shown that the low-albedo and soil difference index (LSDI) can be used to distinguish bare soils from ISA [18] and that the modified normalized difference water index (MNDWI) can be used to separate water from other land-cover types [39]. Thus, both indices were used in this research.

Based on the fraction images, a decision tree classifier was used to classify urban land-cover types. The MNDWI and band5 (ETM+)/band6 (OLI) were used to extract the water bodies. The normalized difference vegetation index (NDVI) and vegetation component were used to extract green space; and LDSI and vegetation component were used to identify ISA. Remaining areas were mainly bare soil, but may also contain other land-cover types. In the next step, unsupervised classification was applied to divide the remaining areas into 100 categories, which were allocated manually to bare soil, ISA, green land, and water bodies. During these steps, appropriate threshold values (identified as " $\mathrm{T}$ " in Figure 2) were used according to the actual spectral signatures of each city (Table 1). Then, an overlay analysis was performed using the urban development boundary and the land-cover maps to extract land-cover information within urban areas.

For each city, we generated a 3-km buffer beyond the 2014 urban build-up boundary. The proportions of four land-cover types within this buffer zone were then calculated [40]. We defined oasis cities as those where vegetation accounted for more than $51.5 \%$ of the area; all other cities were classified as desert cities. Then, the oasis and desert cities were subdivided into industrial and non-industrial cities depending on whether their GDPs were dominated by secondary industries (Different types of cities were shown in Figure 3). 
Table 1. The thresholds used in the decision tree classifier.

\begin{tabular}{|c|c|c|c|c|c|c|c|c|c|c|c|c|c|}
\hline \multirow{2}{*}{ ID } & \multirow{2}{*}{ City } & \multicolumn{6}{|c|}{2000} & \multicolumn{6}{|c|}{2014} \\
\hline & & $\mathrm{T} 1$ & T2 & T3 & $\mathrm{T} 4$ & T5 & T6 & T1 & T2 & T3 & T4 & T5 & T6 \\
\hline 1 & Urumqi & 0.02 & 600 & 0.28 & 0.00 & 0.10 & 0.39 & 0.08 & 1700 & 0.31 & 0.03 & 0.10 & 0.35 \\
\hline 2 & Karamay & 0.10 & 950 & 0.33 & 0.02 & 0.08 & 0.58 & 0.05 & 1600 & 0.35 & 0.02 & 0.08 & 0.34 \\
\hline 3 & Shihezi & 0.10 & 600 & 0.26 & 0.04 & 0.08 & 0.41 & 0.08 & 1450 & 0.27 & 0.02 & 0.08 & 0.48 \\
\hline 4 & Turpan & 0.00 & 500 & 0.35 & 0.00 & 0.10 & 0.45 & 0.00 & 1450 & 0.31 & 0.05 & 0.08 & 0.41 \\
\hline 5 & Hami & 0.00 & 1100 & 0.32 & 0.02 & 0.10 & 0.23 & 0.10 & 1850 & 0.32 & 0.02 & 0.10 & 0.42 \\
\hline 6 & Changji & 0.00 & 700 & 0.37 & 0.00 & 0.10 & 0.48 & 0.02 & 2750 & 0.32 & 0.00 & 0.10 & 0.44 \\
\hline 7 & Yining & 0.00 & 950 & 0.34 & 0.00 & 0.08 & 0.45 & 0.00 & 1600 & 0.26 & 0.00 & 0.08 & 0.42 \\
\hline 8 & Tacheng & 0.04 & 800 & 0.33 & 0.02 & 0.10 & 0.35 & 0.05 & 1400 & 0.29 & 0.02 & 0.10 & 0.41 \\
\hline 9 & Altay & 0.00 & 650 & 0.31 & 0.03 & 0.10 & 0.49 & 0.02 & 1550 & 0.27 & 0.00 & 0.08 & 0.44 \\
\hline 10 & Bole & 0.02 & 650 & 0.41 & 0.00 & 0.12 & 0.38 & 0.00 & 1200 & 0.24 & 0.00 & 0.08 & 0.53 \\
\hline 11 & Korla & 0.00 & 1150 & 0.42 & 0.00 & 0.10 & 0.21 & 0.10 & 2900 & 0.34 & 0.04 & 0.08 & 0.32 \\
\hline 12 & Aksu & 0.10 & 700 & 0.32 & 0.04 & 0.10 & 0.50 & 0.02 & 1100 & 0.29 & 0.02 & 0.10 & 0.62 \\
\hline 13 & Atush & 0.00 & 500 & 0.31 & 0.00 & 0.08 & 0.55 & 0.00 & 1200 & 0.29 & 0.02 & 0.06 & 0.43 \\
\hline 14 & Kashi & 0.01 & 900 & 0.44 & 0.02 & 0.15 & 0.42 & 0.05 & 1850 & 0.33 & 0.00 & 0.10 & 0.30 \\
\hline 15 & Hetian & 0.05 & 700 & 0.41 & 0.02 & 0.10 & 0.30 & 0.00 & 1200 & 0.28 & 0.01 & 0.08 & 0.38 \\
\hline 16 & Jiayuguan & 0.00 & 700 & 0.29 & 0.00 & 0.10 & 0.37 & 0.02 & 1850 & 0.25 & 0.00 & 0.08 & 0.40 \\
\hline 17 & Jinchang & 0.12 & 950 & 0.26 & 0.04 & 0.08 & 0.29 & 0.10 & 1250 & 0.28 & 0.02 & 0.10 & 0.36 \\
\hline 18 & Wuwei & 0.02 & 900 & 0.28 & 0.00 & 0.08 & 0.50 & 0.00 & 1300 & 0.31 & 0.01 & 0.10 & 0.52 \\
\hline 19 & Zhangye & 0.07 & 650 & 0.31 & 0.02 & 0.10 & 0.57 & 0.00 & 1450 & 0.27 & 0.00 & 0.08 & 0.38 \\
\hline 20 & Jiuquan & 0.01 & 1100 & 0.28 & 0.00 & 0.08 & 0.59 & 0.00 & 1350 & 0.31 & 0.00 & 0.08 & 0.39 \\
\hline 21 & Alxa Left & 0.08 & 700 & 0.26 & 0.00 & 0.07 & 0.48 & 0.10 & 1950 & 0.34 & 0.02 & 0.08 & 0.32 \\
\hline
\end{tabular}

\subsubsection{Accuracy Evaluation}

To match the number of sampling points with the size of urban areas, the linear decomposition was used to allocate the 6000 sampling points, of which 50 points for minimum city, 988 points for maximum city. At the city scale, stratified random sampling was adopted to represent different urban land-cover compositions of different cities.

It is challenging to separate ISA from bare soil other land cover types in dryland. Unlike conventional LSMA that identifies the ISA by simply adding up the low albedo and high albedo component [41-43], our study used the LDSI to locate ISA and conducting additional unsupervised classification to identify the land-cover types for "unknown areas". We chose Korla, a typical dryland city with median land area and population size among the investigated cities, as an example to compare the accuracy of our modified LSMA method with that of the conventional LSMA. Table 2 indicates that the modified LSMA method produced higher overall classification accuracy $(86.65 \%)$ compared to conventional method (82.59\%), with both the user's and producer's accuracies of the ISA and Soil types being improved.

Table 2. Comparing the accuracy of our method and the conventional linear spectral mixture analysis method, using the Korla city as an example.

\begin{tabular}{|c|c|c|c|c|c|c|c|c|c|}
\hline \multirow{2}{*}{$\begin{array}{c}\text { Classified } \\
\text { Data }\end{array}$} & \multicolumn{4}{|c|}{ Classified Data } & \multirow{2}{*}{$\begin{array}{l}\text { Reference } \\
\text { Totals }\end{array}$} & \multirow{2}{*}{$\begin{array}{c}\text { Classified } \\
\text { Totals }\end{array}$} & \multirow{2}{*}{$\begin{array}{l}\text { Number } \\
\text { Correct }\end{array}$} & \multirow{2}{*}{$\begin{array}{l}\text { Producer's } \\
\text { Accuracy }\end{array}$} & \multirow{2}{*}{$\begin{array}{c}\text { User's } \\
\text { Accuracy }\end{array}$} \\
\hline & ISA & GV & Soil & Water & & & & & \\
\hline ISA & 197 & 2 & 28 & 0 & 243 & 227 & 197 & $81.07 \%$ & $86.78 \%$ \\
\hline GV & 14 & 94 & 6 & 0 & 103 & 114 & 94 & $91.26 \%$ & $84.21 \%$ \\
\hline Soil & 32 & 7 & 121 & 1 & 155 & 161 & 121 & $78.06 \%$ & $75.16 \%$ \\
\hline \multirow[t]{2}{*}{ Water } & 0 & 0 & 0 & 15 & 16 & 15 & 15 & $93.75 \%$ & $100 \%$ \\
\hline & \multicolumn{9}{|c|}{ Conventional Method: Overall Classification Accuracy $=82.59 \%$ (i.e., 427/517) } \\
\hline ISA & 208 & 1 & 21 & 0 & 243 & 230 & 208 & $85.60 \%$ & $90.43 \%$ \\
\hline GV & 11 & 96 & 5 & 0 & 103 & 112 & 96 & $93.20 \%$ & $85.71 \%$ \\
\hline Soil & 24 & 6 & 129 & 1 & 155 & 160 & 129 & $83.23 \%$ & $80.63 \%$ \\
\hline Water & 0 & 0 & 0 & 15 & 16 & 15 & 15 & $93.75 \%$ & $100 \%$ \\
\hline \multicolumn{10}{|c|}{ Our Method: Overall Classification Accuracy = 86.65\% (i.e., 448/517) } \\
\hline
\end{tabular}




\subsubsection{Change Detection Analysis}

Different scales of urban land-cover information with differing levels of detail can be used to identify dynamic land use changes in arid China. Different urbanized regions helped the researchers understand the impacts of different urbanization levels on land-cover. Landscape ecological indices can effectively reflect the spatial form of urban land-cover types [44]. Therefore, the change detection analysis strategy contained three parts. First, information about changes across the entire arid region was obtained, and the differences between oasis and desert cities were analysed. In addition, the differences between industrial and non-industrial cities were compared in both areas. Second, different levels of urbanization including completed urbanization ("old urban districts") and ongoing urbanization ("new urban districts") were examined. Finally, landscape pattern changes in the land-cover types were highlighted at regional and urban scales.

\subsubsection{Landscape Pattern Analysis}

Many landscape ecology indices exist; however, no any single index is able to provide a comprehensive quantitative description of land-cover patterns. On the other hand, the use of multiple indices sometimes includes repeated or redundant information [44]. Five landscape indices were selected for use (Table 3): patch density (PD), largest patch index (LPI), landscape shape index (LSI), aggregation index (AI), and Shannon's diversity index (SHDI).

Table 3. Detailed information on the landscape indices implemented in Fragstats 4.2 [45].

\begin{tabular}{|c|c|c|c|}
\hline Index & Abbreviation & Expression & Comments \\
\hline Patch Density & PD & $\begin{array}{l}P D=\frac{n_{i}}{A}(10,000)(100) \\
n_{i}: \text { number of patches of type } i \\
A=\text { total landscape area }\left(\mathrm{m}^{2}\right)\end{array}$ & $\begin{array}{l}\text { Expresses the number of patches per unit area and } \\
\text { facilitates comparisons among landscapes of varying sizes. }\end{array}$ \\
\hline $\begin{array}{l}\text { Largest Patch } \\
\text { Index }\end{array}$ & LPI & $\begin{array}{l}L P I=\frac{\max _{j=1}^{n}\left(a_{i j}\right)}{A}(100) \\
a_{i j}=\text { area }\left(\mathrm{m}^{2}\right) \text { of patch } i j \\
A=\text { total landscape area }\left(\mathrm{m}^{2}\right)\end{array}$ & $\begin{array}{l}\text { Quantifies the percentage of total landscape area } \\
\text { represented by the largest patch. A simple measure } \\
\text { of dominance. }\end{array}$ \\
\hline $\begin{array}{l}\text { Landscape } \\
\text { Shape Index }\end{array}$ & LSI & $\begin{array}{l}L S I=\frac{0.25 \sum_{k=1}^{m} e_{i k}^{*}}{\sqrt{A}} \text { or }=\frac{0.25 E^{*}}{\sqrt{A}} \\
E^{*} \text { or } e_{i k}^{*}=\text { total length }(\mathrm{m}) \text { of edge } \\
A=\text { total landscape area }\left(\mathrm{m}^{2}\right)\end{array}$ & $\begin{array}{l}\text { Provides a standardized measure of total edge or edge } \\
\text { density that adjusts for the size of the landscape. } \\
\text { The expression on the left is for the class level; } \\
\text { the expression on the right is for the landscape level. }\end{array}$ \\
\hline $\begin{array}{l}\text { Aggregation } \\
\text { Index }\end{array}$ & $\mathrm{AI}$ & $\begin{array}{l}A I=\left[\frac{g_{i i}}{\max \rightarrow g_{i i}}\right] \text { or }\left[\sum_{i=1}^{m}\left(\frac{g_{i i}}{\max \rightarrow g_{i i}}\right) P_{i}\right] \\
g_{i i}=\text { number of like adjacencies for type } i \\
\text { max } \rightarrow g_{i i}=\text { maximum } g_{i i} \\
P_{i}=\text { proportion of landscape type } i\end{array}$ & $\begin{array}{l}\text { Shows the frequency of different pairs of patch types, or is } \\
\text { an area weighted mean class aggregation index, where } \\
\text { each class is weighted by its proportional area in the } \\
\text { landscape. The expression on the left is for the class level; } \\
\text { the expression on the right is for the landscape level. }\end{array}$ \\
\hline $\begin{array}{l}\text { Shannon's } \\
\text { Diversity } \\
\text { Index }\end{array}$ & SHDI & $\begin{array}{l}S H D I=-\sum_{i=1}^{m} P_{i} \operatorname{In}\left(P_{i}\right) \\
P_{i}=\text { proportion of the landscape occupied } \\
\text { by patch type (class) } i\end{array}$ & $\begin{array}{l}\text { A popular measure of diversity in community ecology that } \\
\text { is applied to landscapes here. }\end{array}$ \\
\hline
\end{tabular}

\subsubsection{Impacts of Economic Conditions on Urban Land-Cover Change}

The ISA has become an indicator of the conversion from natural surfaces to artificial land during urbanization; this conversion changes the proportions of land-cover types within urban areas [19]. We analysed whether ISA and socio-economic conditions (i.e., GDP and population) were positively correlated. A positive correlation would indicate that socio-economic factors have had driving effects on urbanization and urban land-cover changes. In addition, GDP density was used to determine whether the local economies had experienced significant growth. Population density was used to explore the ability of oasis and desert cities to attract new residents. 


\section{Results}

\subsection{Analysis of Urban Land Cover Classification Results}

The overall classification accuracy for land-cover types in arid China was 90.37\% (Table 4). Most misclassifications occurred among ISA, bare soil and water. This error was reasonable because complex building materials and different surface colors resulted in a broad spectral signature for the ISA. Dark ISA had a low spectral reflectance that was easily confused with shadows and water, while light ISA was highly reflective and had similar spectral characteristics to bare soil. Thus, accurately distinguishing between these surface types was a challenge. Although LSDI and MNDWI were used to improve the classification accuracy, the producer's accuracy and user's accuracy for bare soil were still the lowest compared to the other land-cover types. At the city scale, the overall accuracy and kappa coefficient ranged from $86.00 \%$ to $93.22 \%$ and from 0.796 to 0.896 , respectively.

\subsection{Analysis of Urban Land-Cover Changes between 2000 and 2014}

\subsubsection{Dynamic Characteristics of Urban Land-Cover in Arid Region of China}

The results (Table 5) showed that urban build-up boundary area increased from $844.83 \mathrm{~km}^{2}$ to $1270.39 \mathrm{~km}^{2}$ in 2000-2014, which represents an increase of $425.56 \mathrm{~km}^{2}$. During this period, ISA increased by $376.40 \mathrm{~km}^{2}$ (an increase of $13.18 \%$ in urban areas), which suggests that urban living space became more compact. Bare soil decreased by $11.08 \mathrm{~km}^{2}$ (a decrease of $13.33 \%$ in urban areas), which indicates that urbanization in this region has increased the capacity of fixed sand and dust. While the urban proportions of vegetation $(+0.27 \%)$ and water $(-0.10 \%)$ remained stable, indicating that important ecological services within urban spaces had been maintained. The ISA and bare soil were dominated by different types of urban land-cover and changed at similar change rates.

\subsubsection{Changes of Spatial Distribution and Land-Cover in Different City Types}

As showed in Figure 3 and Table 6, the spatial distribution of urban land-cover types in oasis cities indicated that new urban areas primarily expanded into vegetated areas, and that the total urban area increased by $43.70 \%$. In contrast, in desert cities, urban areas expanded significantly into the surrounding desert, and the total urban area increased by $62.90 \%$. Regarding dynamic change of land-cover types, the expansion of ISA and vegetation caused the decreases of bare soil in oasis cities. The ISA increased, while vegetation and bare soil decreased in desert cities. The difference was the fraction of vegetation increased for $2.66 \%$ in oasis cities and decreased by $1.62 \%$ in desert cities. Furthermore, the changes in land-cover types between non-industrial cities and industrial cities in both oasis and desert regions also varied, especially for vegetation (Table 4 ). The changes in vegetation correlated with the city's surrounding environment (oasis or desert) and economic attributes (industrial and non-industrial). 
Table 4. Accuracy evaluation of urban land-cover classification in arid China.

\begin{tabular}{|c|c|c|c|c|c|c|c|c|c|c|c|}
\hline \multirow{2}{*}{ Classified Data } & \multicolumn{4}{|c|}{ Classified Data } & \multirow{2}{*}{$\begin{array}{l}\text { Reference } \\
\text { Totals }\end{array}$} & \multirow{2}{*}{$\begin{array}{c}\text { Classified } \\
\text { Totals }\end{array}$} & \multirow{2}{*}{$\begin{array}{c}\text { Number } \\
\text { Correct }\end{array}$} & \multirow{2}{*}{$\begin{array}{c}\text { Producer's } \\
\text { Accuracy }\end{array}$} & \multirow{2}{*}{$\begin{array}{l}\text { User's } \\
\text { Accuracy }\end{array}$} & & \\
\hline & ISA & GV & Soil & Water & & & & & & & \\
\hline ISA & 2553 & 37 & 182 & 5 & 2819 & 2777 & 2553 & $90.56 \%$ & $91.93 \%$ & & \\
\hline GV & 68 & 1445 & 45 & 0 & 1524 & 1558 & 1445 & $94.82 \%$ & $92.75 \%$ & & \\
\hline water & 0 & 0 & 0 & 176 & 182 & 176 & 176 & $96.70 \%$ & $100 \%$ & & \\
\hline \multicolumn{12}{|c|}{ Overall Classification Accuracy $=90.37 \%$ (i.e., 5422/6000), Overall Kappa Statistics $=0.854$} \\
\hline City & Urumqi & Shi Hezi & Korla & Yi Ning & Ha Mi & Chang Ji & Zhang Ye & Karamay & Aksu & Ka Shi & \\
\hline OCA:\% & 93.22 & 91.00 & 86.65 & 88.83 & 89.95 & 92.19 & 89.76 & 92.42 & 89.47 & 90.77 & \\
\hline Kappa & 0.896 & 0.862 & 0.796 & 0.828 & 0.846 & 0.880 & 0.842 & 0.884 & 0.837 & 0.858 & \\
\hline City & Alxa Left & Jin Chang & Jiu Quan & Jia Yuguan & Bo Le & Wu Wei & He Tian & Ta Cheng & Altay & Turpan & Atush \\
\hline NSP & 243 & 254 & 210 & 190 & 199 & 151 & 143 & 122 & 92 & 67 & 50 \\
\hline OCA:\% & 88.89 & 88.98 & 89.05 & 90.53 & 89.45 & 92.72 & 89.51 & 89.34 & 90.22 & 89.55 & 86.00 \\
\hline Kappa & 0.832 & 0.829 & 0.830 & 0.854 & 0.839 & 0.887 & 0.838 & 0.837 & 0.851 & 0.840 & 0.783 \\
\hline
\end{tabular}

Abbreviation: NSP—Number of Sampling Point; OCA—Overall Classification Accuracy. 
Table 5. Dynamic characteristics of urban land-covers between 2000 and 2014.

\begin{tabular}{|c|c|c|c|c|c|c|c|c|c|c|}
\hline \multirow[b]{2}{*}{ ID } & \multirow[b]{2}{*}{ City } & \multirow{2}{*}{$\begin{array}{c}\text { Build-Up } \\
\text { Area Change } \\
\left(\mathrm{km}^{2}\right)\end{array}$} & \multicolumn{2}{|c|}{ ISA } & \multicolumn{2}{|c|}{ GV } & \multicolumn{2}{|c|}{ SOIL } & \multicolumn{2}{|c|}{ WATER } \\
\hline & & & $\underset{\left(\mathbf{k m}^{2}\right)}{\triangle \mathrm{A}}$ & $\begin{array}{l}\triangle f \\
(\%)\end{array}$ & $\underset{\left(\mathbf{k m}^{2}\right)}{\triangle \mathrm{A}}$ & $\begin{array}{l}\triangle f \\
(\%)\end{array}$ & $\underset{\left(\mathbf{k m}^{2}\right)}{\triangle \mathrm{A}}$ & $\begin{array}{l}\triangle f \\
(\%)\end{array}$ & $\underset{\left(\mathbf{k m}^{2}\right)}{\triangle \mathrm{A}}$ & $\begin{array}{l}\triangle f \\
(\%)\end{array}$ \\
\hline 1 & Urumqi & 96.13 & 108.96 & 12.36 & 8.45 & -1.29 & -22.09 & -11.03 & 0.81 & -0.03 \\
\hline 2 & Karamay & 23.04 & 13.36 & 13.42 & 4.06 & 3.72 & 5.48 & -16.67 & 0.13 & -0.47 \\
\hline 3 & Shihezi & 47.23 & 43.02 & 16.77 & 8.84 & 2.64 & -4.16 & -18.4 & -0.45 & -1.02 \\
\hline 4 & Turpan & 3.56 & 2.43 & 8.74 & -0.36 & -7.74 & 1.47 & -1.16 & 0.03 & 0.16 \\
\hline 5 & Hami & 17.14 & 16.4 & 14.97 & 1.06 & -0.87 & -0.29 & -14.07 & -0.01 & -0.04 \\
\hline 6 & Changji & 16.48 & 15.03 & 11.74 & 7.5 & 11.48 & -6.23 & -23.46 & 0.19 & 0.24 \\
\hline 7 & Yining & 34.63 & 29.6 & 16.78 & 6.73 & 1.12 & -1.72 & -17.76 & 0.03 & -0.12 \\
\hline 8 & Tacheng & 2.34 & 4.96 & 19.67 & -0.35 & -3.42 & -2.25 & -16.21 & -0.01 & -0.03 \\
\hline 9 & Altay & 5.6 & 5.53 & 23 & 1.76 & 8.14 & -1.71 & -31.19 & 0.01 & 0.06 \\
\hline 10 & Bole & 13.66 & 8.52 & 12.84 & -1.11 & -10.67 & 6.1 & -0.86 & 0.15 & -1.31 \\
\hline 11 & Korla & 39.63 & 26.26 & 11.02 & 3.35 & -2.03 & 9.3 & -9.13 & 0.72 & 0.14 \\
\hline 12 & Aksu & 9.02 & 13.67 & 22.77 & 0.83 & -0.96 & -5.78 & -22.37 & 0.31 & 0.58 \\
\hline 13 & Atush & 1.06 & 2.27 & 21.42 & 0.6 & 6.21 & -1.79 & -27.28 & -0.02 & -0.36 \\
\hline 14 & Kashi & 11.39 & 13.6 & 19.87 & 3.11 & 4.03 & -5.06 & -22.88 & -0.26 & -1.01 \\
\hline 15 & Hetian & 6.32 & 7.65 & 23.39 & -0.53 & -6.89 & -0.8 & -16.46 & 0.00 & -0.04 \\
\hline 16 & Jiayuguan & 13.14 & 11 & 8.78 & 5.18 & 8.46 & -3.34 & -17.75 & 0.29 & 0.5 \\
\hline 17 & Jinchang & 20.54 & 12.71 & 8.75 & 0.12 & -8.5 & 7.69 & -0.21 & 0.02 & -0.03 \\
\hline 18 & Wuwei & 10.86 & 7.3 & 6.12 & 2.73 & 8.58 & 0.6 & -15.49 & 0.22 & 0.8 \\
\hline 19 & Zhangye & 16.18 & 11.59 & 14.24 & 2.32 & 2.37 & 2.31 & -15.8 & -0.05 & -0.8 \\
\hline 20 & Jiuquan & 19.17 & 12.35 & 13.5 & 1.75 & -1.95 & 4.96 & -11.74 & 0.11 & 0.19 \\
\hline 21 & Alxa Left & 18.44 & 10.19 & 10.65 & 1.79 & -3.67 & 6.23 & -7.38 & 0.22 & 0.4 \\
\hline 22 & Total & 425.56 & 376.4 & 13.18 & 57.81 & 0.24 & -11.08 & -13.33 & 2.43 & -0.1 \\
\hline
\end{tabular}

Notes: ISA-Impervious Surface Area; GV-Green Vegetation; $\triangle \mathrm{A}$ was defined as the difference of ISA (or GV, Soil, Water) area in 2014 and 2000; $\triangle \mathrm{f}(\triangle$ fraction) was defined as the difference between the ratio of ISA (or GV, Soil, Water) area and urban-up area in 2014 and the corresponding ratio in 2000.

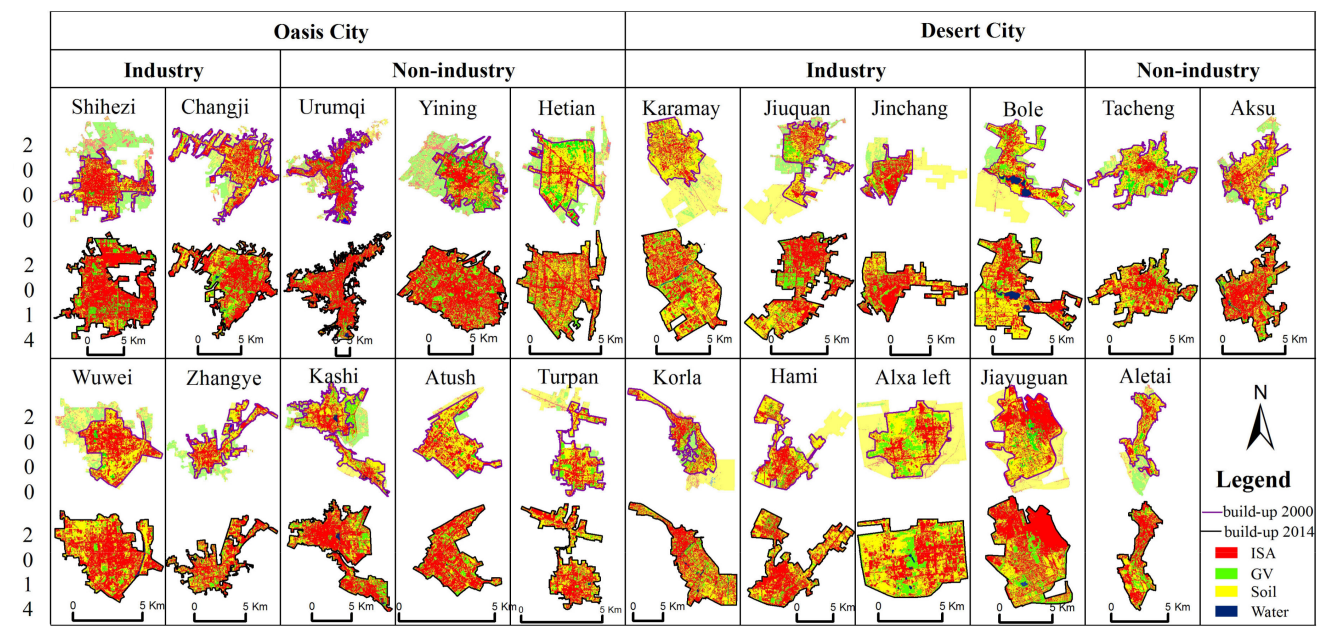

Figure 3. Land-cover maps of the 21 major arid cities in China in 2000 and 2014. In this picture, the scale was set at fixed value of $5 \mathrm{~km}$, and its length varied with the size of each city, respectively.

Table 6. Changes in urban build-up area and land-covers during 2000-2014 by city types.

\begin{tabular}{|c|c|c|c|c|}
\hline Changes in & \multicolumn{2}{|c|}{ Oasis Cities } & \multicolumn{2}{|c|}{ Desert Cities } \\
\hline Build-up & \multicolumn{2}{|c|}{$+43.70 \%$} & \multicolumn{2}{|c|}{$+62.90 \%$} \\
\hline ISA & \multicolumn{2}{|c|}{$+14.59 \%$} & \multicolumn{2}{|c|}{$+14.98 \%$} \\
\hline GV & \multicolumn{2}{|c|}{$+2.66 \%$} & \multicolumn{2}{|c|}{$-1.62 \%$} \\
\hline Bare soil (\%) & \multirow{2}{*}{\multicolumn{2}{|c|}{$\begin{array}{c}-17.17 \% \\
-0.09 \%\end{array}$}} & \multicolumn{2}{|c|}{$-13.24 \%$} \\
\hline Water & & & \multicolumn{2}{|c|}{$-0.12 \%$} \\
\hline Changes in & Industrial Cities & Non-Industrial Cities & Industrial Cities & Non-Industrial Cities \\
\hline Build-up & $+58.32 \%$ & $+38.21 \%$ & $+74.12 \%$ & $+25.18 \%$ \\
\hline ISA & $+10.85 \%$ & $+17.09 \%$ & $+12.42 \%$ & $+21.81 \%$ \\
\hline GV & $+7.79 \%$ & $-0.76 \%$ & $-2.70 \%$ & $+1.25 \%$ \\
\hline Bare soil & $-18.77 \%$ & $-16.10 \%$ & $-9.48 \%$ & $-23.26 \%$ \\
\hline Water & $+0.13 \%$ & $-0.24 \%$ & $-0.24 \%$ & $+0.20 \%$ \\
\hline
\end{tabular}




\subsubsection{Changes of Land-Cover Transfer in Different Urbanization Levels}

Changes of land-cover transfer in different urbanization can be summarized in Table 7. In old urban districts, ISA increased by $191.44 \mathrm{~km}^{2}$, of which $22.17 \%$ was formerly vegetation and $77.83 \%$ was previously bare soil. Thus, the contribution from bare soil was 3.51 times that of vegetation. A large amount of bare soil had already disappeared. In addition, the area converted from bare soil to vegetation equalled $88.38 \%$ of the lost vegetated area; thus, the proportion of vegetation in old urban districts only slightly decreased by $0.48 \%$. However, in new urban districts, $41.76 \%$ of the new ISA was converted from former vegetation and $58.24 \%$ from previous bare soil. The contribution from bare soil was 1.39 times that of vegetation, which indicates an increasing loss of vegetation in new compared to old urban districts. With the conversion of bare soil to vegetation also decreasing, the fraction of vegetation substantially decreased by $9.96 \%$ in new urban districts.

Table 7. Land cover transfer matrix for different urbanization levels during 2000-2014 (units: area, km²).

\begin{tabular}{cccccc}
\hline Old Urban District & ISA & GV & Soil & Water & 2000 Total \\
\hline ISA & 414.76 & 0.00 & 0.00 & 0.00 & 414.76 \\
GV & 42.45 & 65.43 & 0.30 & 0.45 & 108.63 \\
Soil & 148.99 & 38.18 & 126.27 & 0.75 & 314.19 \\
Water & 0.00 & 0.31 & 0.75 & 6.19 & 7.25 \\
2014 total & 606.20 & 103.92 & 127.32 & 7.39 & 844.83 \\
\hline New Urban District & ISA & GV & Soil & Water & 2000 Total \\
\hline ISA & 15.97 & 0.00 & 0.00 & 0.00 & 15.97 \\
GV & 70.85 & 31.98 & 0.88 & 0.56 & 104.27 \\
Soil & 98.82 & 29.76 & 173.94 & 1.13 & 303.65 \\
Water & 0.00 & 0.00 & 0.31 & 1.36 & 1.67 \\
2014 total & 185.64 & 61.74 & 175.13 & 3.05 & 425.56 \\
\hline
\end{tabular}

\subsubsection{Patterns of Landscape Change}

Between 2000 and 2014, the urban landscape in arid China has become more integrated $(\mathrm{PD}=-0.51$; SHDI $=-0.09$; Figure $4 \mathrm{a})$. The fragmentation of all land-cover types increased, except for that of ISA (Figure $4 \mathrm{~b}$ ). During this period, the urban landscape became more complex in oasis industrial cities $(\mathrm{PD}=+0.91)$ and desert non-industrial cities $(\mathrm{PD}=+1.40)$. However, it became less complex (more integrated) in oasis non-industrial cities $(\mathrm{PD}=-0.98)$ and desert industrial cities $(\mathrm{PD}=-0.63)$. All indices (LPI, AI, LSI) showed increasing trends and SHDI decreased. However, the LPI, AI, and SHDI showed opposite tendencies in desert non-industrial cities. because the degree to which the desert non-industrial cities expanded was relatively small $(+25.18 \%)$ and land-cover changes were primarily concentrated in old urban districts; thus, these changes increased the degree of land-cover fragmentation ( $\mathrm{PD}=+1.40)$, reduced the LPI $(-0.17)$ and $\mathrm{AI}(-1.93)$, and increased the SHDI (+0.02), reflecting increasing complexity (Figure $4 \mathrm{c})$.

At the land-cover types, the process of urbanization increased the AI and LPI, and decreased PD for ISA. The conversion of bare soil and vegetation to ISA caused both to be embedded in ISA, which led to opposite landscape changes (Figure $4 \mathrm{~d}-\mathrm{f}$ ). An interesting commonality between all of the land-cover types was that LSI values reflected increasing complexity (Figure 4g). However, the desert industrial cities showed different trends in the LPI for soil and the PD for green vegetation (GV). The main reason for this result was that spatial agglomeration associated with the distribution of bare soil increased the LPI $(+0.14)$, and relatively small vegetation patches resulted in a lower PD $(-0.15)$ in new urban districts within desert industrial cities compared to other city types. 

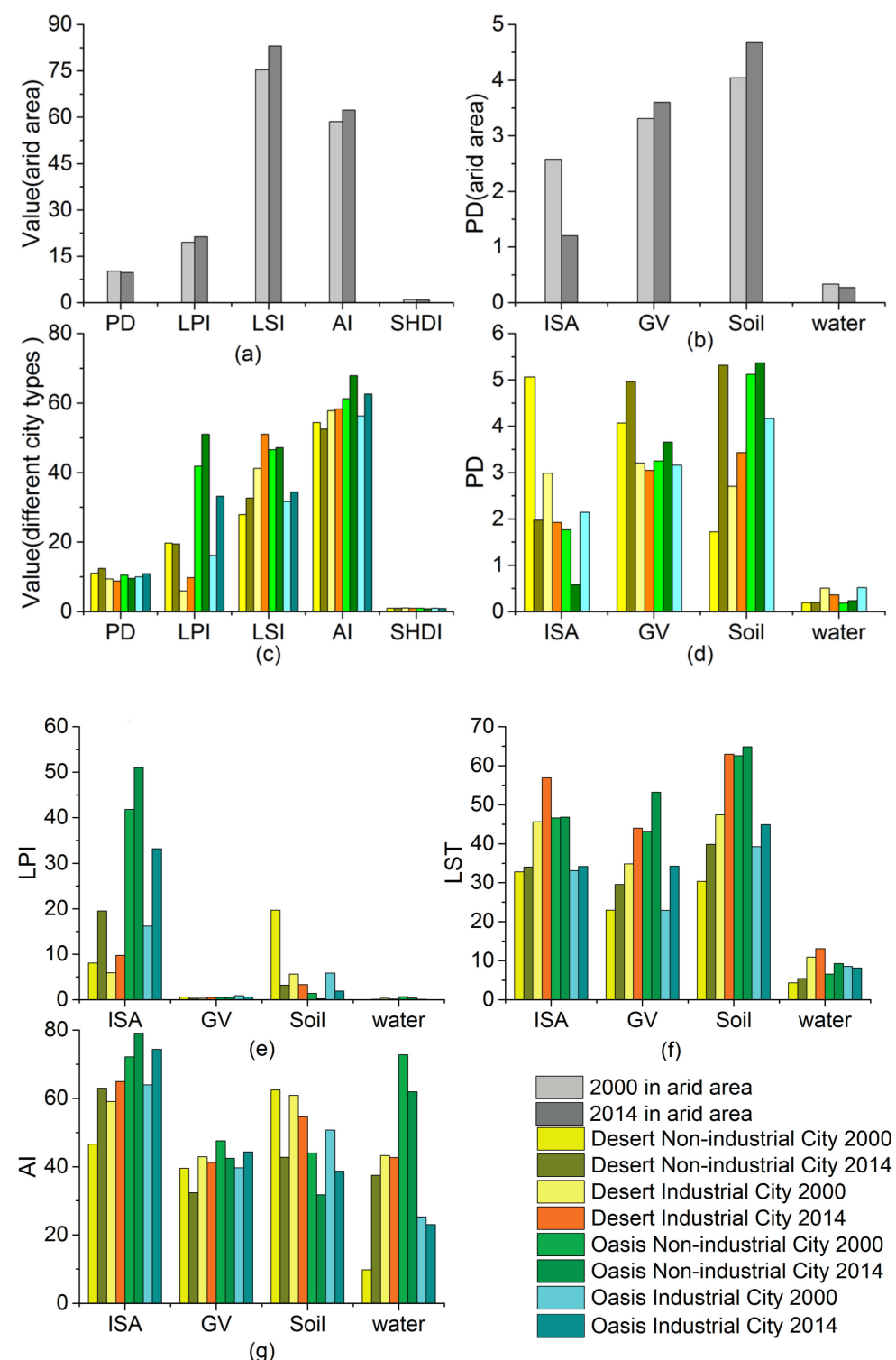

Figure 4. Landscape index change characteristics from 2000 to 2014. Abbreviations: patch density: PD; largest patch index: LPI; landscape shape index: LSI; aggregation index: AI; Shannon's diversity index: SHDI. The meaning of color columns: $(\mathbf{a}, \mathbf{b})$ light grey for the time of 2000 in arid China, dark grey for the time of 2014 in arid China; (c-g) golden yellow for desert non-industrial city in 2000, brown for desert non-industrial city in 2014, sunny yellow for desert industrial city in 2000, orange yellow for desert industrial city in 2014, light green for oasis non-industrial city in 2000, dark green for oasis non-industrial city in 2014, light blue for oasis industrial city in 2000, dark blue for oasis industrial city in 2014.

\subsection{Analysis of the Relationship between Socio-Economic Conditions and Urban Land-Cover Changes}

The correlation between GDP and ISA was significant $\left(R^{2}=0.7838, P<0.05\right)$, and GDP density reflected a positive change from 2000 to 2014 (Figure 5). Therefore, the economy in arid China developed rapidly, causing the ISA to increase sharply. With the increasing of ISA, the extent of the urban area and the ratio of land-cover types also changed. In addition, GDP density was closely related to urban area. GDP density increased the most in desert industrial cities $(+8.234)$, followed by oasis industrial cities (+4.648), non-industrial oasis cities (+3.599), and non-industrial desert cities (+2.567). These results are consistent with the proportional changes in the urban areas of these city types $(+74.12 \%,+58.32 \%,+38.21 \%$, and $+25.18 \%$, respectively), as shown in Table 4 . 


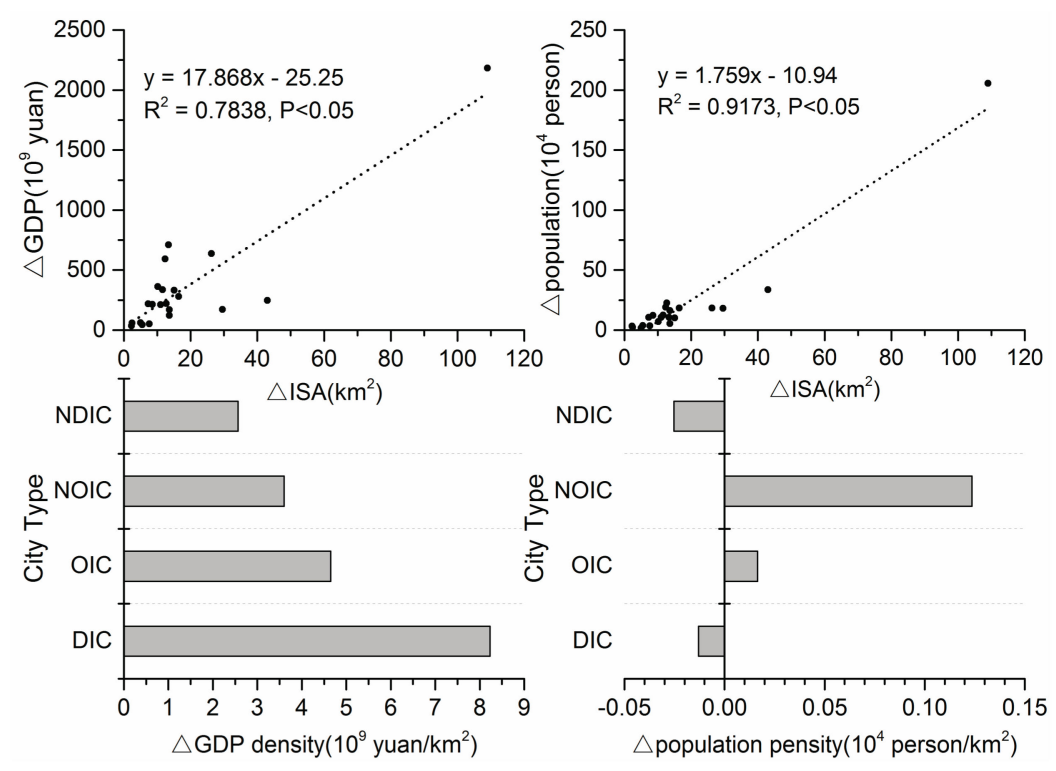

Figure 5. Socioeconomic characteristics related to urban land-cover changes. Abbreviations: NDIC: non-desert industrial city; DIC: desert industrial city; NOIC: non-oasis industrial city; OIC: oasis industrial city. The symbol $\triangle$ represents a change.

Population growth also significantly increased ISA $\left(\mathrm{R}^{2}=0.9173, P<0.05\right)$. However, the population density increased by an average $11.82 \%$ in oasis cities (industrial cities: $2.39 \%$; non-industrial cities: $18.24 \%$ ), whereas it decreased by an average $2.36 \%$ in desert cities (industrial cities: $-1.76 \%$; non-industrial cities: $-4.45 \%$ ). These results indicate that oasis cities had a strong ability to attract new residents (+3.15 million), especially non-industrial oasis cities (+2.50 million). However, desert cities were primarily characterized by industries and surrounded by fragile natural environmental conditions. The urban area of the studied desert cities greatly increased by $62.90 \%$ and population growth was relatively small (+1.31 million), which led to a lower population density.

\section{Discussion}

\subsection{Comparison of Urban Land-Cover Changes among Different Regions}

Information related to urban land-cover change helps researchers understand rapid urbanization in arid region of China. This paper found the impervious surface area in urban areas increased by $+13.23 \%$ and bare soil decreased by $-13.41 \%$, while vegetation $(+0.27 \%)$ and water $(-0.10 \%)$ remained stable (Table 3). These results differed from the findings obtained by Yan et al. (2015) [23], who indicated that ISA increased and GV decreased in the city of Urumqi. The analysis of land-cover dynamics in Yan et al.'s study was focused on the period from 1990 to 2010 and focused on a single city. We found that the fractions of ISA in the major cities of arid China ranged from $41 \%$ to $75 \%$ in 2014 , with a mean value of $62 \%$, which was significantly lower than that $(75 \%)$ identified in the humid cities of eastern China (including Beijing, Guangzhou, etc.), but closer to the ISA fraction (56\%) of American cities (including Chicago, New York, and Los Angeles [26]). This difference in ISA\% between the western and eastern cities in China might be related to the city population density, which was much lower in the dryland cities of western China than in the eastern cities [46,47]. Additionally, many studies that analyse dynamic urban land-cover characteristics were based on fixed areas (survey areas, image boundaries or pre-defined areas) $[43,48,49]$, while the results reported in this paper considered changes to the built-up areas and thus provide more detailed information. 


\subsection{The Urbanization Characterized by Expansion of ISA and Reduction of Bare Soil}

This study showed that the urbanization in arid China was characterized by the dramatic expansion of ISA and reduction of bare soil. It had only a minor effect on green ecosystems, such as vegetation productivity and coverage. By contrast, the urbanization in humid cities of eastern China was a different situation, in that the ever-expanding ISA usually took up a large number of farmland, green land and water bodies, resulting in the degradation of ecosystem services [50]. As we know, rapid urbanization has occurred in most parts of China in the past three decades due to growing population and economy, especially in eastern China [41,42]. In the context of limited land and ecological resources, this study suggests that urban expansion should be promoted in western China and strictly controlled in eastern China. This could be addressed by reducing farmland reclamation in western China and protecting farmland in eastern China [51]. However, the land use changes in China currently run against this proposal. Dramatic urban expansion and sharply farmland loss occurred in eastern China, while urban areas and farmland both increased in western China. Therefore, we suggest that, a comprehensive analysis of urban land-cover changes and their ecological impacts in different eco-regions be used to adjust urban and agricultural land management strategies to promote urbanization in western China. Besides, it is also in line with the economic development project entitled "New Silk Road Economic Belt".

\subsection{Increasing Harmonization of Urbanization and Greening in Arid China}

The present study showed that the fractions of vegetation in arid cities remained essentially steady from 2000 to 2014 (Table 3). In other words, the processes of urbanization and greening were increasingly harmonized, which was particularly significant for the sustainability of fragile urban ecosystems in arid regions. The land-cover transfer matrix included the conversion of bare soil to vegetation and then to ISA (Table 5), indicating that vegetation was an intermediate stage in the urbanization process. In this conversion process, the vegetation equilibrium represents unchanged, lost, and new vegetation, which were measured at rates of $39.31 \%, 22.94 \%$, and $37.75 \%$, respectively. Meanwhile, the fractions of vegetation decreased slightly $(-0.48 \%)$ in old urban districts and decreased sharply $(-9.96 \%)$ in new urban districts (Table 5). In addition, urban vegetation experienced considerable fragmentation with patches becoming isolated from each other by the ever-expanding impervious surfaces (Figure 3). The increases in AI and LSI indicated intensified interactions between humans and the ecological space. This suggests that, under the arid climate and relatively fragile ecosystems, rapid urbanization causes the urban ecological environment to become more sensitive to human disturbances in arid regions compared to other eco-zones [52]. In this process, the incorporating greening into the process of urbanization plays a vital role in maintaining ecological service, improving the living environment, and preventing erosion.

This paper also showed that vegetation was particularly sensitive in both oasis and desert cities (Table 4). In oasis areas, vegetation represents a potential impediment to urban expansion $(43.70 \%)$, because it is required to maintain ecological services in arid regions. Within these urban areas, vegetated areas increased by $61.27 \%$ compared to itself during the study period. In desert areas, where urban areas expanded by $62.90 \%$, urbanization was characterized by significant expansion into the desert with no obstacles. In these cities, vegetated areas itself increased by $39.21 \%$, and new vegetation was primarily planted in desert area at great economic cost due to the extremely fragile ecological environment [53]. The increase of vegetation itself was obvious in both areas. However, the process of greening in desert cities, particularly in desert industrial cities, was slower than that in oasis cities (Table 4). These findings suggest that a large amount of vegetation needs to be planted to improve the living environment of desert cities and to increase their ability for attracting new residents, which is conducive to the sustainable development of fragile urban ecosystems and socio-economic conditions in desert cities. 


\subsection{Environmental Effects}

The environmental effects of urban land-cover changes in arid regions were notably different from those in humid regions because of the large areas of bare soil around and within arid urban areas. These environmental effects included a change in the nature of region's role in the carbon cycle. With the rapid urbanization of arid China from 2000 to 2014, low-density bare soil carbon "sources" turned into ISA carbon "sinks" [11], and high-density vegetation carbon "sources" experienced an unstable dynamic equilibrium due to the process of land-cover conversion. Another effect of land-cover changes was the inversion of urban heat island phenomenon (UHI) in the warm seasons. In humid areas, there was positive correlation between ISA and land surface temperatures (LST). The everexpanding ISA increased the urban heat island effect $[49,54]$. However, in arid region, the lower albedo of bare soil compared to ISA caused bare soil to absorb more energy in the daytimes and to therefore had a higher temperature [55]. In arid China, the urban LST displayed a decreasing trend in response to the transformation of bare soil $(-13.41 \%)$ to ISA $(+13.23 \%)$ during the daytimes in warm seasons. It is noteworthy that urban heat scape could be very complex in the winter season, when prominent heat island effect was found in the industrial areas while cool island effect was found in urban residential areas in a coastal industrial city [46]. Although the arid urban areas in the northwestern China are far from sea, and thus avoid the complex interactions between the maritime-climate and land-cover feedbacks, the impacts from snow cover on urban climate can also complicate the urban heat scape in the winter time.

\section{Conclusions}

Four land-cover types (impervious surfaces, vegetation, bare soil, and water bodies) were extracted from Landsat data using a hybrid classification method for all cities that serve as administrative centers in arid China. The new 15-m resolution urban land-cover products had an overall kappa coefficient of 0.85 and a classification accuracy of $90.37 \%$. The process of urbanization in this region has been characterized by the dramatic expansion of ISA and reduction of bare soil, while vegetation levels remained in a dynamic equilibrium. The fractions of vegetation decreased slightly in old urban districts and decreased sharply in new urban districts. The changes in vegetation correlated with the city's surrounding environment (oasis or desert) and economic attributes (industrial and non-industrial). From an economic perspective, socio-economic conditions showed significant positive correlations with ISA and affected urban land-cover changes. Oasis cities had a stronger ability to attract new residents than desert cities. To ensure the sustainability of fragile urban ecosystems in arid China, the harmony between urbanization and greening should made a priority. In addition, urban and agricultural land management strategies should be properly adjusted to promote urbanization in western China.

Acknowledgments: This study was supported by the National Basic Research Programs of China (Grant No. 2014CB954204); Zhejiang Agriculture \& Forestry University's Research and Development Fund (2013FR052); The academic backbone project of Northeast Agricultural University (16XG07). Natural Natural Science Foundation of China (Grant No. 41601582). We thank the reviewers for their valuable comments and suggestions that help us improve this manuscript.

Author Contributions: Chi Zhang conceived and designed the experiments; Tao Pan conducted the image processing and resultant analysis; Tao Pan, Dengsheng Lu, Chi Zhang wrote the paper. All authors revised the paper.

Conflicts of Interest: The authors declare no conflict of interest. The founding sponsors had no role in the design of the study; in the collection, analyses, or interpretation of data; in the writing of the manuscript, and in the decision to publish the results.

\section{References}

1. Grimm, N.B.; Faeth, S.H.; Golubiewski, N.E.; Redman, C.L.; Wu, J.; Bai, X.; Briggs, J.M. Global change and the ecology of cities. Science 2008, 319, 756-760. [CrossRef] [PubMed] 
2. Lutz, W.; Sanderson, W.C.; Scherbov, S. The end of world population growth. Nature 2001, 412, 543-545. [CrossRef] [PubMed]

3. Seto, K.C.; Fragkias, M.; Güneralp, B.; Reilly, M.K. A meta-analysis of global urban land expansion. PLoS ONE 2011, 6, e23777. [CrossRef] [PubMed]

4. Schneider, A. Monitoring land cover change in urban and peri-urban areas using dense time stacks of Landsat satellite data and a data mining approach. Remote Sens. Environ. 2012, 124, 689-704. [CrossRef]

5. Seto, K.C.; Güneralp, B.; Hutyra, L.R. Global forecasts of urban expansion to 2030 and direct impacts on biodiversity and carbon pools. Proc. Natl. Acad. Sci. USA 2012, 109, 16083-16088. [CrossRef] [PubMed]

6. Davies, Z.G.; Edmondson, J.L.; Heinemeyer, A.; Leake, J.R; Gaston, K.J. Mapping an urban ecosystem service: Quantifying above-ground carbon storage at a city-wide scale. J. Appl. Ecol. 2011, 48, 1125-1134.

7. Seto, K.C.; Shepherd, J.M. Global urban land-use trends and climate impacts. Curr. Opin. Environ. Sustain. 2009, 1, 89-95. [CrossRef]

8. Lee, J.G.; Heaney, J.P. Estimation of urban imperviousness and its impacts on storm water systems. J. Water Resour. Plan. Manag. 2003, 129, 419-426. [CrossRef]

9. Wu, J.J. Making the case for landscape ecology an effective approach to urban sustainability. Landsc. J. 2008, 27, 41-50. [CrossRef]

10. Kuang, W.; Liu, J.; Zhang, Z.; Lu, D.; Xiang, B. Spatiotemporal dynamics of impervious surface areas across China during the early 21st century. Chin. Sci. Bull. 2013, 58, 1691-1701. [CrossRef]

11. Zhang, Y.; Odeh, I.O.; Han, C. Bi-temporal characterization of land surface temperature in relation to impervious surface area, NDVI and NDBI, using a sub-pixel image analysis. Int. J. Appl. Earth Obs. Geoinf. 2009, 11, 256-264. [CrossRef]

12. Amiri, R.; Weng, Q.; Alimohammadi, A.; Alavipanah, S.K. Spatial-temporal dynamics of land surface temperature in relation to fractional vegetation cover and land use/cover in the Tabriz urban area, Iran. Remote Sens. Environ. 2009, 113, 2606-2617. [CrossRef]

13. Kuang, W.; Chi, W.; Lu, D.; Dou, Y. A comparative analysis of megacity expansions in China and the US: Patterns, rates and driving forces. Landsc. Urban Plan. 2014, 132, 121-135. [CrossRef]

14. Li, J.; Song, C.; Cao, L.; Zhu, F.; Meng, X.; Wu, J. Impacts of landscape structure on surface urban heat islands: A case study of Shanghai, China. Remote Sens. Environ. 2011, 115, 3249-3263. [CrossRef]

15. Wu, J.; Desertification, R.R. Plant Sciences for Students; Macmillan Reference: New York, NY, USA, 2001.

16. Lin, M.-L.; Chen, C.-W. Application of fuzzy models for the monitoring of ecologically sensitive ecosystems in a dynamic semi-arid landscape from satellite imagery. Eng. Comput. 2010, 27, 5-19. [CrossRef]

17. Kepner, W.G.; Watts, C.J.; Edmonds, C.M.; Maingi, J.K.; Marsh, S.E.; Luna, G. A landscape approach for detecting and evaluating change in a semi-arid environment. In Monitoring Ecological Condition in the Western United States; Springer: Berlin, Germany, 2000; pp. 179-195.

18. Zhang, C.; Chen, Y.; Lu, D. Mapping the land-cover distribution in arid and semiarid urban landscapes with Landsat Thematic Mapper imagery. Int. J. Remote Sens. 2015, 36, 4483-4500. [CrossRef]

19. Zhang, Y.; Yang, D.; Zhang, X.; Dong, W.; Zhang, X. Regional structure and spatial morphology characteristics of oasis urban agglomeration in arid area-A case of urban agglomeration in northern slope of Tianshan Mountains, Northwest China. Chin. Geogr. Sci. 2009, 19, 341-348. [CrossRef]

20. Myint, S.W.; Okin, G.S. Modelling land-cover types using Multiple Endmember Spectral Mixture Analysis in a desert city. Int. J. Remote Sens. 2009, 30, 2237-2257. [CrossRef]

21. Li, X.; Myint, S.W.; Zhang, Y.; Galletti, C.; Zhang, X.; Turner, B.L. Object-based land-cover classification for metropolitan Phoenix, Arizona, using aerial photography. Int. J. Appl. Earth Obs. Geoinf. 2014, 33, 321-330. [CrossRef]

22. Wulder, M.A.; Masek, J.G.; Cohen, W.B.; Loveland, T.R.; Woodcock, C.E. Opening the archive: How free data has enabled the science and monitoring promise of Landsat. Remote Sens. Environ. 2012, 122, 2-10. [CrossRef]

23. Yan, Y.; Zhang, C.; Hu, Y.F.; Kuang, W.H. Urban Land-Cover Change and Its Impact on the Ecosystem Carbon Storage in a Dryland City. Remote Sens. 2016, 8, 6. [CrossRef]

24. Lu, D.; Moran, E.; Batistella, M. Linear mixture model applied to Amazonian vegetation classification. Remote Sens. Environ. 2003, 87, 456-469. [CrossRef]

25. Wu, C.; Murray, A.T. Estimating impervious surface distribution by spectral mixture analysis. Remote Sens. Environ. 2003, 84, 493-505. [CrossRef] 
26. Chi, W.; Shi, W.; Kuang, W. Spatio-temporal characteristics of intra-urban land cover in the cities of China and USA from 1978 to 2010. J. Geogr. Sci. 2015, 25, 3-18. [CrossRef]

27. Guo, W.; Lu, D.; Wu, Y.; Zhang, J. Mapping Impervious Surface Distribution with Integration of SNNP VIIRS-DNB and MODIS NDVI Data. Remote Sens. 2015, 7, 12459-12477. [CrossRef]

28. Lu, D.; Moran, E.; Hetrick, S. Detection of impervious surface change with multitemporal Landsat images in an urban-rural frontier. ISPRS J. Photogramm. Remote Sens. 2011, 66, 298-306. [CrossRef] [PubMed]

29. Stefanov, W.L.; Ramsey, M.S.; Christensen, P.R. Monitoring urban land cover change: An expert system approach to land cover classification of semiarid to arid urban centers. Remote Sens. Environ. 2001, 77, 173-185. [CrossRef]

30. Li, B.; Chen, Y.; Shi, X. Why does the temperature rise faster in the arid region of northwest China? J. Geophys. Res. Atmos. 2012, 117. [CrossRef]

31. Wang, H.; Chen, Y.; Chen, Z. Spatial distribution and temporal trends of mean precipitation and extremes in the arid region, northwest of China, during 1960-2010. Hydrol. Process. 2013, 27, 1807-1818. [CrossRef]

32. Module, F. Atmospheric Correction Module: QUAC and FLAASH User's Guide. Version 2009, 4, 44.

33. Bernstein, L.; Adler-Golden, S.; Sundberg, R.; Ratkowski, A. Improved Reflectance Retrieval from Hyper-and Multispectral Imagery without Prior Scene or Sensor Information. In Remote Sensing of Clouds and the Atmosphere XI; SPIE-International Society for Optics and Photonics: Bellingham, WA, USA, 2006; pp. 63622P-63628P.

34. Liu, J.; Liu, M.; Zhuang, D.; Zhang, Z.; Deng, X. Study on spatial pattern of land-use change in China during 1995-2000. Sci. China Ser. D Earth Sci. 2003, 46, 373-384.

35. Liu, J.Y.; Zhang, Z.X.; Zhuang, D.F.; Wang, Y.M.; Zhou, W.C.; Zhang, S.W.; Li, R.D.; Jiang, N.; Wu, S.X. A study on the spatial-temporal dynamic changes of land-useand driving forces analyses of China in the 1990s. Geogr. Res. 2003, 22, 1-12.

36. Lu, D.; Li, G.; Kuang, W.; Moran, E. Methods to extract impervious surface areas from satellite images. Int. J. Digit. Earth 2014, 7, 93-112. [CrossRef]

37. Lu, D.; Li, G.; Moran, E.; Batistella, M.; Freitas, C.C. Mapping impervious surfaces with the integrated use of Landsat Thematic Mapper and radar data: A case study in an urban-rural landscape in the Brazilian Amazon. ISPRS J. Photogramm. Remote Sens. 2011, 66, 798-808. [CrossRef]

38. Ehlers, M.; Klonus, S.; Johan Åstrand, P.; Rosso, P. Multi-sensor image fusion for pansharpening in remote sensing. Int. J. Image Data Fusion 2010, 1, 25-45. [CrossRef]

39. Han-qiu, X. A Study on Information Extraction of Water Body with the Modified Normalized Difference Water Index (MNDWI). J. Remote Sens. 2005, 5, 589-595.

40. Zhang, C.; Tian, H.; Chen, G.; Chappelka, A.; Xu, X.; Ren, W.; Hui, D.; Liu, M.; Lu, C.; Pan, S. Impacts of urbanization on carbon balance in terrestrial ecosystems of the Southern United States. Environ. Pollut. 2012, 164, 89-101. [CrossRef] [PubMed]

41. Fan, F.; Fan, W.; Weng, Q. Improving Urban Impervious Surface Mapping by Linear Spectral Mixture Analysis and Using Spectral Indices. Can. J. Remote Sens. 2015, 41, 577-586. [CrossRef]

42. Adams, J. Classification of multispectral images based on fractions of endmembers: Application to land-cover change in the Brazilian Amazon. Remote Sens. Environ. 1995, 52, 137-154. [CrossRef]

43. Lu, D.; Weng, Q. Use of impervious surface in urban land-use classification. Remote Sens. Environ. 2006, 102, 146-160. [CrossRef]

44. Zurlini, G.; Riitters, K.H.; Zaccarelli, N.; Petrosillo, I. Patterns of disturbance at multiple scales in real and simulated landscapes. Landsc. Ecol. 2007, 22, 705-721. [CrossRef]

45. Spatial Pattern Analysis Program for Categorical and Continuous Maps. Available online: http://www. umass.edu/landeco/research/fragstats/documents/fragstats.help.4.2.pdf (accessed on 21 April 2015).

46. Aina, Y.A.; Parvez, I.M.; Balogun, A.-L. Examining the Effect of Land Use on the Spatiotemporal Dynamics of Urban Temperature in an Industrial City: A Landsat Imagery Analysis; Springer: Berlin, Germany, 2017; pp. 3-15.

47. Smits, P.C.; Dellepiane, S.G.; Schowengerdt, R.A. Quality assessment of image classification algorithms for land-cover mapping: A review and a proposal for a cost-based approach. Int. J. Remote Sens. 1999, 20, 1461-1486. [CrossRef]

48. Shuster, W.; Bonta, J.; Thurston, H.; Warnemuende, E.; Smith, D. Impacts of impervious surface on watershed hydrology: A review. Urban Water J. 2005, 2, 263-275. [CrossRef] 
49. Xiao, R.-B.; Ouyang, Z.-Y.; Zheng, H.; Li, W.-F.; Schienke, E.W.; Wang, X.-K. Spatial pattern of impervious surfaces and their impacts on land surface temperature in Beijing, China. J. Environ. Sci. 2007, 19, 250-256. [CrossRef]

50. Liu, J.Y.; Kuang, W.H.; Zhang, Z.X.; Xu, X.L.; Qin, Y.W.; Ning, J.; Zhou, W.C.; Zhang, S.W.; Li, R.D.; Yan, C.Z.; et al. Spatiotemporal characteristics, patterns, and causes of land-use changes in China since the late 1980s. J. Geogr. Sci. 2014, 24, 195-210. [CrossRef]

51. Cheng, G. Evolution of the Concept of Carrying Capacity and the Analysis Framework of Water Resources Carrying Capacity in Northwest of China. J. Glaciol. Geocryol. 2002, 24, 361-367.

52. Chen, Y.; Day, S.D.; Wick, A.F.; Strahm, B.D.; Wiseman, P.E.; Daniels, W.L. Changes in soil carbon pools and microbial biomass from urban land development and subsequent post-development soil rehabilitation. Soil Biol. Biochem. 2013, 66, 38-44. [CrossRef]

53. Wickens, G.E. Ecophysiology of Economic Plants in Arid and Semi-Arid Lands; Springer Science \& Business Media: Berlin, Germany, 2013.

54. Yan, Y.; Kuang, W.; Zhang, C.; Chen, C. Impacts of impervious surface expansion on soil organic carbon-A spatially explicit study. Sci. Rep. 2015, 5. [CrossRef] [PubMed]

55. Lazzarini, M.; Marpu, P.R.; Ghedira, H. Temperature-land cover interactions: The inversion of urban heat island phenomenon in desert city areas. Remote Sens. Environ. 2013, 130, 136-152. [CrossRef]

(c) 2017 by the authors. Licensee MDPI, Basel, Switzerland. This article is an open access article distributed under the terms and conditions of the Creative Commons Attribution (CC BY) license (http://creativecommons.org/licenses/by/4.0/). 